\title{
Factors That Influence Consumer Decision in Wedding Vendor Selection
}

\author{
Muhamad Randy Wiguna Semesta, Idqan Fahmi, and Siti Jahroh \\ Sekolah Bisnis IPB, Institut Pertanian Bogor, Bogor \\ Email: \\ randywiguna@gmail.com
}

\begin{abstract}
The purpose of this study is to analyze consumers' perceptions of wedding vendors to the current marketing mix of services, reference groups, and purchase decisions. Analyze the effect of the services marketing mix and reference group on the purchase decision. Formulate an effective marketing strategy for wedding vendors in influencing consumer purchasing decisions. 208 people of samples, with purposive sampling. Analytical tools use descriptive analysis, SEM-PLS, and IPA. Consumer perception of service marketing mix and purchase decision is a good category, while the reference group is in fair category. Services marketing mix has a significant positive effect on the purchasing decisions of the wedding vendor, while the reference group has no significant effect on the purchasing decisions of the wedding vendor.Marketing strategies that can be improved to improve purchasing decisions so that is following the priority indicators that have a high level of importance, but have a level of performance that is still below average.
\end{abstract}

Keywords: consumer behavior, reference group, service marketing mix, the wedding vendor.

\begin{abstract}
Abstrak: Penelitian ini bertujuan untuk menganalisis persepsi konsumen vendor pernikahan terhadap marketing mix jasa, kelompok acuan dan keputusan pembelian. Menganalisis pengaruh marketing mix jasa dan kelompok referensi pada keputusan pembelian. Merumuskan strategi pemasaran untuk vendor pernikahan dalam mempengaruhi keputusan pembelian konsumen. Jumlah sampel adalah 208 orang, dengan purposive sampling. Alat analisis menggunakan analisis deskriptif, SEM-PLS dan IPA. Persepsi konsumen terhadap marketing mix jasa dan keputusan pembelian berada dalam kategori baik, sedangkan kelompok acuan pada kategori cukup. Marketing mix jasa berpengaruh positif signifikan terhadap keputusan pembelian vendor pernikahan. Sedangkan kelompok acuan tidak berpengaruh signifikan terhadap keputusann pembelian vendor pernikahan. Strategi pemasaran yang dapat dimplementasikan dalam meningkatkan keputusan pembelian vendor pernikahan adalah dengan meningkatkan prioritas indikator variabel yang memiliki tingkat kepentingan tinggi, namun masih memiliki tingkat kinerja dibawah rata-rata.
\end{abstract}

Kata kunci: kelompok acuan, marketing mix jasa, perilaku konsumen, vendor pernikahan. 


\section{INTRODUCTION}

The wedding industry is attractive in Indonesia with a capital turnover of more than US \$ 7 billion / year (IDR 94 trillion / year) (Tempo.co., 2017). Quite a lot of wedding fairs are held in Indonesia each year with large transaction value and are usually only held within three days. JWF (Jakarta Wedding Festival) for example in 2019 is targeting a transaction of IDR 600 billion with an increase of $20 \%$ from the previous year, WCF (Wedding Celebration Festival) in 2018 had a transaction target of IDR 350 billion, GPI (Gebyar Pernikahan Indonesia) had a transaction target of IDR 75 billion in 2019.

The value of the wedding industry transaction value is supported by the large budget needed to hold a wedding party. The amount of budget required is following the number of guests. Based on data released by (Bridestory, 2017), the budget required to prepare a wedding party is at least IDR 25-40 million and can reach more than IDR 600 million. The large turnover of capital in the wedding industry attracts many businessmen, which makes the business environment in this industry more competitive.

Bridestory already has more than 20,000 registered wedding vendors. Meanwhile, at Weddingku there are already 10,000 wedding vendors registered. Apart from the wedding vendors that have been registered in the Weddingku and Bridestory marketplaces, there are still many wedding vendors who have not been registered. A large number of wedding vendors show that a wedding based business is an attractive business.

The attractiveness of marriage-based businesses makes the business environment even more competitive. The competitive business environment is also influenced by the number of marriages in Indonesia which is quite large but tends to decline. In Figure 1, it can be seen that a large number of marriages in the 2012-2016 period in Indonesia experienced a downward trend. The decline in the number of marriages in Indonesia has pushed competition among wedding vendors to be tighter. Each wedding vendor competes to attract consumers to buy their products. Wedding vendor businesses need the right and efficient strategy to attract consumers to buy products. The right strategy can be implemented if the wedding vendor can understand the factors that consumers consider in choosing a wedding vendor.

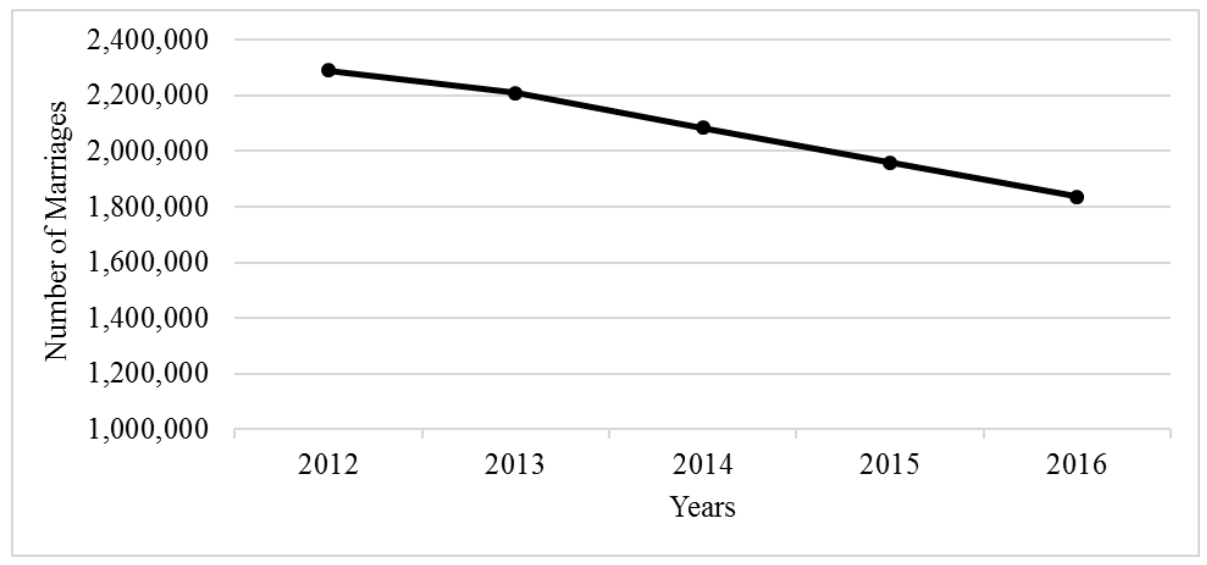

Figure 1. Number of Marriages in Indonesia

Source: (Kementerian Agama RI, 2016) 
The marketing strategy that is often applied by business people is the service marketing mix. The company seeks to influence the response of the target market through a service marketing mix. Service marketing mix variables can be created in such a way by wedding vendor marketers to attract consumers to buy their services. According to (Zeithaml et al., 2018), the marketing mix variable must be reviewed and changed based on the actual consumer perspective, no marketing mix variable remains the same, whether intentional or unplanned changes will always occur.

In addition to the marketing mix of services, which can influence consumer decisions in choosing a wedding vendor is the reference group. According to (Sumarwan, 2014) from a marketing perspective, the reference group can provide a standard of assessment as a basis for comparison for someone who influences decisions. Purchase and consumption.

Looking at the phenomena and various problems that exist, this research must be conducted to analyze consumer perceptions of the service marketing mix, reference groups, and purchasing decisions. Analyze the effect of the service marketing mix and reference groups on purchasing decisions of wedding vendors, and formulate effective marketing strategies in improving purchasing decisions.

\section{THEORETICAL REVIEW}

Buying decision. (Schiffman and Wisenblit, 2015) developed a consumer purchasing decision model consisting of three components including input, process, and output. Input consists of the marketing mix, socio-cultural influence, and also the source of communication. The process component focuses on how consumers make decisions that are influenced by internal factors, namely consumer psychology. The decision process includes identifying needs, types of decisions, seeking information before buying and evaluating purchase alternatives. Furthermore, the output of the purchase decision includes purchasing behavior and post-purchase evaluation.

Wedding Vendors. According to KBBI, vendors are people who sell (sellers). Meanwhile, a Wedding is a ceremony that is celebrated or carried out to formalizing wedding bonds properly in terms of religious norms, legal norms, or social norms. If the two words are combined into a wedding vendor, it means the person who sells (sellers) the services of all necessities related to the wedding ceremony or party. According to (Bridestory, 2017), the basic needs of a wedding party include venue, decoration, catering, bridal make-up, photographers, invitations, souvenirs, and others. According to (Weddingwire, 2018), the main vendors ordered include photography, venue, hair and makeup, wedding clothes, flowers, and wedding cakes. (Bridestory, 2017) considers the factors that consumers consider sequentially including price, portfolio, reviews, personality, response speed, location, and vendor experience. (Widjaja, 2015) in choosing a wedding vendor the need for convenience is the highest need, group sources are the main source of information, and price attributes are the main evaluation attributes. (Fu et al., 2018) the average cost of a wedding per family has increased, since 1970. Furthermore, in the study, it was also stated that the costs incurred by the groom were greater than the costs incurred by the bride. (Guan et al., 2015) stated that there is the push and pull factors in choosing wedding banquet venues including four driving factors identified including seeking relaxation and knowledge, fulfilling prestige, escaping from daily routines, and social networking. Furthermore, the six 
attractive factors consist of budget, atmosphere, facilities, wedding services, transportation, and quality and service. (Huang et al., 2017) required professional skills for wedding planners to be able to deliver their services successfully and smoothly. Among them, marketing abilities are the most important, followed by self-management abilities, professional competences, and team-work abilities. For this reason, training is needed for anyone interested in becoming a wedding planner.

Marketing mix services. A collection of marketing tools that consists of products, promotions, prices, and a place of nature tactical controlled, combine by the company to generate a response that is wanted in the target market and influence product demand, is called the Marketing mix (Kotler and Armstrong, 2008). (Zeithaml et al., 2018) added that for service companies besides the $4 \mathrm{p}$ concept, there are three marketing mix variables, including people, processes, and physical evidence that can be used to communicate with consumers.

The service mix marketing relationship to purchasing decisions. Several previous studies related to the effect of service marketing mix on purchasing decisions have been carried out, but they are not specific to wedding vendors. Some of these studies include (Purnama and Murwatiningsih, 2014) with the object of research visiting the Ranggawarsita Museum, (Putra et al., 2015) with the object of research on delivery services, (Wulan et al., 2016) with the object of research into cinnamon restaurants, (Sukotjo and Radix, 2010) with the object of beauty clinic research, (Chayana, 2014) with the research object of house of balloon, (Kavanillah, 2018) with the object of hotel research, (Ramadhanti, 2017) with the research object of Giant Supermarket, (Marwa et al., 2014) with the research object of individual life insurance, (Tjahjono et al., 2013) with the research object of women's clothing which states that the marketing mix of services has a significant effect on purchasing decisions. (Harahap, 2015) there were positive and significant influences between variable range of products and prices on consumer purchasing decisions in Pajak USU (Pajus) Medan.

Reference Group. According to (Sumarwan, 2014), a one or group of people who significantly influence a person's behavior is called a reference group. The influence of the reference group can be in the form of normative influence, informational, and value expression. Influence in the form of social norms that must be obeyed and followed is called normative influence. The effect that is a carrier to express value is called the effect of value expression. The effect due to having better knowledge and information is called the information effect.

Reference Group Relationship with Purchasing Decisions. (Fernandes and Panda, 2015) state that the reference group greatly influences the consumption behavior of female consumers compared to male consumers. (Edward and Erikson, 2014) show that social pressure such as family, friends, and media has a significant effect on buying interest in preloved products. (Sangkakoon et al., 2014) concluded that the reference group consisting of children, spouses, parents, and friends influenced the interest in buying a house. (Wardhani, 2015) argues that someone else's opinion has a significant effect on consumer purchasing decisions, while family factors (family opinion) do not influence consumer 
purchasing decisions in Jakarta. (Ris, 2014), consumer decisions are simultaneously significantly influenced by family and reference groups. (Razak et al., 2013) consumer purchasing decisions are strongly influenced by the reference group. (Novita et al, 2014) Simultaneously variable family and reference group significant effect against consumer decisions buy special cosmetics men brand VaselineMen at Pekanbaru. (Yuniarti, 2015) reference group and family have a significant effect on the decision to purchase Jambi Batik among students of the Faculty of Economics and Business, Jambi University. (Tuwo and Pandowo, 2015) reference groups, family, and, roles and status have a significant influence and family is the most dominant to the customers purchase intention in using wedding organizers.

Conceptual Thinking. Wedding vendor purchasing decisions are significantly influenced by the service marketing mix variables and the reference group. The results of the analysis of consumer perceptions of the service marketing mix variables and the reference group together with their influence on the wedding vendor purchasing decisions serve as the basis for formulating an effective marketing strategy. In Figure 2, you can see the conceptual framework in this study.

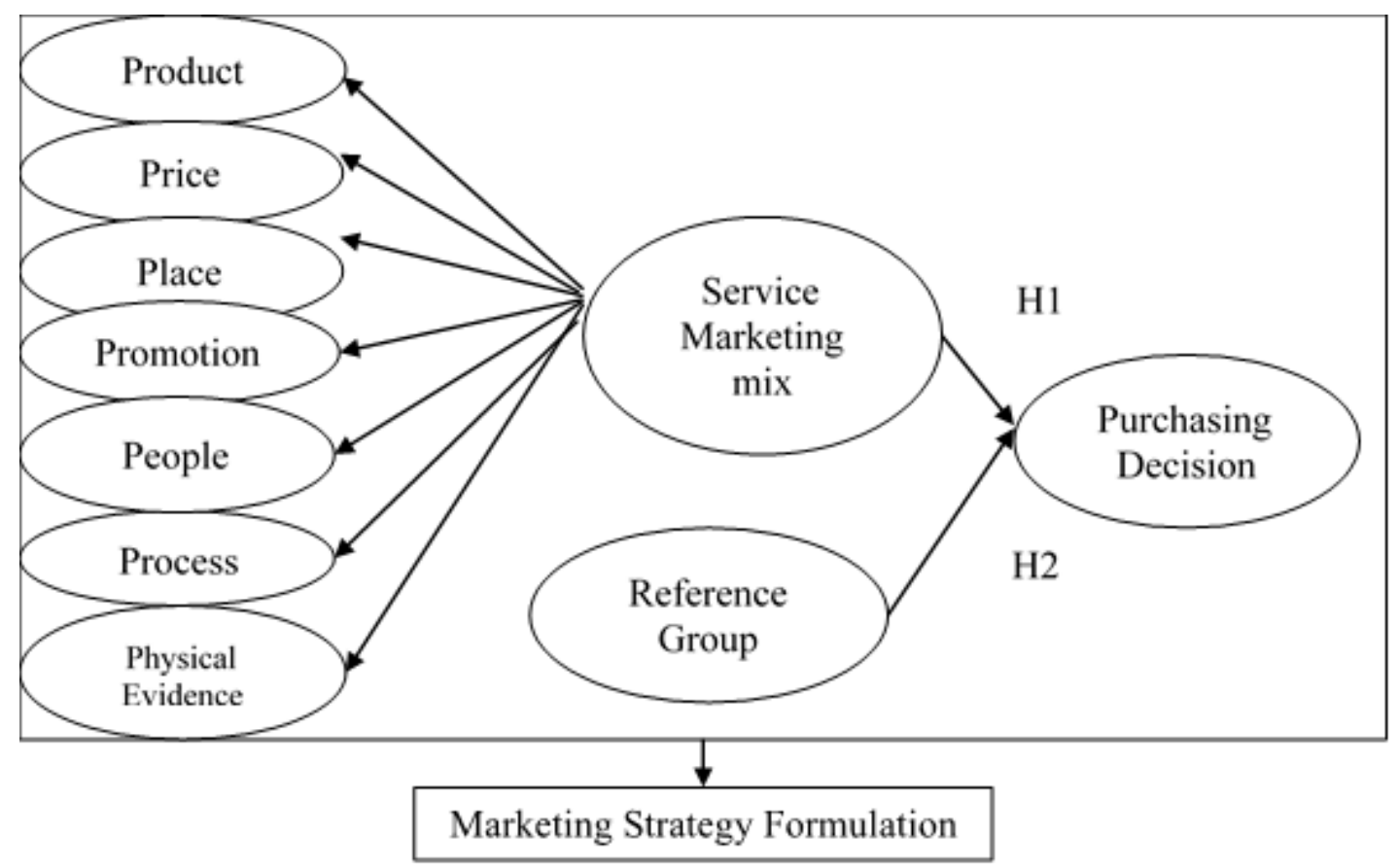

Figure 2. Conceptual framework

H1: The service marketing mix influences the wedding vendor purchasing decisions.

H2: The reference group influences the wedding vendor purchasing decisions. 


\section{METHODS}

The study was conducted on wedding vendor consumers in the period July 2019-June 2020. The design of this study used a cross-sectional survey design, using primary and secondary data. The sampling technique purposive sampling was used to determine the respondents to suit the research needs. Respondents of this study are married consumers, using wedding vendors, with an age range of 20-35 years (millennial generation) who reside in big cities in Indonesia. This study used a total sample of 208 people. Data related to respondent characteristics and consumer behavior were analyzed using descriptive analysis and processed quantitatively using scores and percentages. Furthermore, the relationship between variables was analyzed using the SEM-PLS analysis method. For the formulation of strategic priorities using IPA analysis (Importance performance analysis), by looking at the performance and importance level of a variable indicator.

This study uses endogenous variables, purchasing decisions, and exogenous variables, namely the service marketing mix and reference groups. This study uses a study of variables and indicators in Table 1.

Table 1. Variables and Research Indicators

\begin{tabular}{|c|c|c|}
\hline Variables & Indicator & Code \\
\hline \multirow{3}{*}{ Product $^{\mathrm{a}}$} & Quality of products & Prod1 \\
\hline & Range of products & Prod2 \\
\hline & Diversity of products & Prod3 \\
\hline \multirow[t]{3}{*}{ Price $^{\mathrm{s}}$} & Lower price & Har1 \\
\hline & Price according to quality & Har2 \\
\hline & flexible payment period & Har3 \\
\hline \multirow[t]{3}{*}{ Place $^{\text {s }}$} & Able to serve consumers outside the region & Tem1 \\
\hline & Strategic office location & Tem2 \\
\hline & Guarantee product availability & Tem3 \\
\hline \multirow[t]{3}{*}{ Promotions } & Interesting ad & Prom1 \\
\hline & Frequently attend wedding vendor fairs & Prom2 \\
\hline & Offer attractive promos & Prom3 \\
\hline \multirow[t]{3}{*}{ People $^{\mathrm{s}}$} & Having friendly employees & Org1 \\
\hline & Having responsive employees & Org2 \\
\hline & Having employees who master the products offered & Org3 \\
\hline \multirow[t]{3}{*}{ Process } & The easy way of ordering & Pros 1 \\
\hline & Fast service process & Pros 2 \\
\hline & Low level of consumer involvement & Pros 3 \\
\hline Physical & Attractive portfolio (product overview) & Buf1 \\
\hline \multirow{2}{*}{ Evidence } & Attractive website or social media & Buf2 \\
\hline & Attractive (uniform) appearance & Buf3 \\
\hline \multirow[t]{2}{*}{ Reference Group ${ }^{\mathrm{s}}$} & Family Recommendations & KA1 \\
\hline & Friend Recommendation & KA2 \\
\hline Purchasing & Buying confidence & KP1 \\
\hline \multirow[t]{2}{*}{ decisions } & Product satisfaction & KP2 \\
\hline & Recommendations & KP3 \\
\hline $\begin{array}{r}\text { Source: }{ }^{\text {a }} \text { (Kotler an } \\
{ }^{\mathrm{b}} \text { (Zeitham } \\
{ }^{\mathrm{c}} \text { (Sumarw } \\
{ }^{\mathrm{d}} \text { (Schiffm }\end{array}$ & $\begin{array}{l}\text { Armstrong, 2008) } \\
\text { et al., 2018) } \\
\text { a 2014) } \\
\text { and Wisenblit, 2015); (Fatrina et al. 2019); (Yah }\end{array}$ & \\
\hline
\end{tabular}




\section{RESULT AND DISCUSSION}

Overview of Respondents. This study used 208 respondents to answer several questions related to the research variables. The majority of respondents were female, namely $93.7 \%$ or as many as 195 respondents. Most of the respondents live in West Java, namely 96 people or around $46.2 \%$. Furthermore, most of the respondents in this study were aged 20-25 years, namely as many as 104 people or $50 \%$.

Most of the respondents' education level is undergraduate, namely $55.3 \%$ of the respondents, namely as many as 115 respondents. Most of the respondents work as housewives, as many as 88 people or $44.2 \%$. Most of the respondents' monthly expenses ranged from IDR 2,500,000 to IDR 4,000,000 per month or 31.3\%. Most of the respondents' wedding years were in 2018 and 2019, namely 66 people or $31.7 \%$.

Wedding Vendor Consumer Consumption Behavior. The bride and groom are the main sources of decision making in the selection of wedding vendors, namely $38.9 \%$ or as many as 81 people. The largest source of funding for the wedding party came from the families of the groom and the bride, amounting to $27.4 \%$ or as many as 57 respondents. Most of the respondents answered that it took them 3-6 months to prepare for the wedding, as many as 74 people or $35.6 \%$. Most of the respondents married in August, as many as 26 people or $12.5 \%$.

Most of the expenses required to hold a wedding party ranged from IDR 50,000,000 to IDR $100,000,000$, with $45.2 \%$ of respondents or as many as 94 people. Besides, most of the respondents answered that the number of guests invited to the wedding was around 101500 as many as 88 people, or $42.3 \%$ of respondents. Based on the respondents' answers, most of the respondents needed one vendor to hold a wedding party, as many as 77 people or $37 \%$. The vendors used include bridal make-up, decoration, catering, invitations, photography, and souvenirs.

Wedding Vendor Consumer Perceptions of the Service Marketing Mix, Reference Groups, and Purchasing Decisions. Assessment of consumer perceptions based on respondents' answers to the questionnaire given regarding the service marketing mix variables, reference groups, and purchasing decisions. The consumer's perception shows the level of performance of each variable indicator and is described by the average score of the respondents' answers. With an average score of <2.33 in the bad category, 2.33-3.67 in the fair category, and $>3.67$ in the good category.

Table 2. Consumer Perceptions of the Service Marketing Mix

\begin{tabular}{cccccc}
\hline $\begin{array}{c}\text { Variable } \\
\text { Dimensions }\end{array}$ & $\begin{array}{c}\text { Variable } \\
\text { Indicators }\end{array}$ & $\begin{array}{c}\text { Mean } \\
\text { Indicator }\end{array}$ & $\begin{array}{c}\text { Indicator } \\
\text { description }\end{array}$ & $\begin{array}{c}\text { Variable } \\
\text { Mean }\end{array}$ & $\begin{array}{c}\text { Description } \\
\text { Dimensions } \\
\text { Variable }\end{array}$ \\
\hline \multirow{2}{*}{ Product } & Prod1 & 3.639 & Fair & & Good \\
& Prod2 & 4.038 & Good & 3.910 & Good \\
& Prod3 & 4.053 & Good & & Good \\
Price & Har1 & 3.861 & Good & 4.034 &
\end{tabular}




\begin{tabular}{|c|c|c|c|c|c|}
\hline \multirow{3}{*}{ Place } & Tem1 & 3.707 & Good & \multirow{3}{*}{3.732} & \multirow{3}{*}{ Good } \\
\hline & Tem2 & 3.639 & Fair & & \\
\hline & Tem3 & 3.851 & Good & & \\
\hline & Prom1 & 3.476 & Fair & \multirow{4}{*}{3.591} & \multirow{4}{*}{ Fair } \\
\hline \multirow[t]{3}{*}{ Promotion } & Prom2 & 3.51 & Fair & & \\
\hline & Prom3 & 3.788 & Good & & \\
\hline & Org1 & 4.115 & Good & & \\
\hline \multirow[t]{3}{*}{ People } & Org2 & 4.005 & Good & \multirow[t]{3}{*}{4.056} & \multirow[t]{3}{*}{ Good } \\
\hline & Org3 & 4.048 & Good & & \\
\hline & Pros1 & 4.019 & Good & & \\
\hline \multirow[t]{2}{*}{ Process } & Pros2 & 3.957 & Good & \multirow[t]{2}{*}{3.913} & \multirow[t]{2}{*}{ Good } \\
\hline & Pros3 & 3.764 & Good & & \\
\hline \multirow{3}{*}{$\begin{array}{l}\text { Physical } \\
\text { Evidence }\end{array}$} & Buf1 & 4.01 & Good & \multirow{3}{*}{3.709} & \multirow{3}{*}{ Good } \\
\hline & Buf2 & 3.558 & Fair & & \\
\hline & Buf3 & 3.558 & Fair & & \\
\hline \multicolumn{4}{|c|}{ Total Mean } & 3.849 & Good \\
\hline
\end{tabular}

Table 2 shows that the total average service marketing mix variables are in a good category. Meanwhile, at the variable dimension level, the promotion variable dimension is in the fair category. The reason is that two indicators of promotional variables, namely attractive advertisements (Prom1) and attractive promos (Prom2) still have poor performance. Based on consumer perceptions, wedding vendors still haven't optimized attractive advertisements (Prom1) and attractive promos (Prom2). Wedding vendors still rarely use advertisements and promos, even if there are not yet according to consumer needs.

Table 3. Reference Group Indicator Performance Level

\begin{tabular}{lccc}
\hline Code & Indicator & Mean & Categori \\
\hline KA1 & Family Recommendation & 3.505 & Fair \\
KA2 & Friend Recommendation & 3.019 & Fair \\
\hline
\end{tabular}

In Table 3, it can be seen that the performance level of the reference group indicators is in a fair category. Recommendations given by reference groups are not always by consumer needs. Reference group recommendations are one source of information, but not the only source of information that will be used as material for consumer evaluation or consideration. Recommendations given by the reference group are not mandatory, but only as additional information for evaluation materials.

Table 4. Purchase decision indicator performance level

\begin{tabular}{cccc}
\hline Code & Indicator & Mean & Category \\
\hline Prod1 & Buying confidence & 4.13 & Good \\
Prod2 & Product Satisfaction & 4.096 & Good \\
Prod3 & Recommendation & 3.976 & Good \\
\hline
\end{tabular}

In Table 4, it can be seen that the level of performance of purchasing decisions is in a good category, both in terms of Buying confidence, product satisfaction, and recommendations. 
Evaluation of Model Fit Level. This study uses the SEM-PLS analysis method processed with SmartPLS 3.0 software. The model path diagram can be seen in Figure 3.

Evaluate the Outer Model. According to (Latan and Ghozali, 2015), PLS can predict and test predictable relationships between constructs and the relationship between constructs and their indicators. Evaluation of the outer model and also the evaluation of the inner model are needed to evaluate the PLS model. Convergent validity tests, discriminant validity tests, and composite reliability are ways that can be done to evaluate the validity and reliability of the outer model (Latan and Ghozali, 2015).

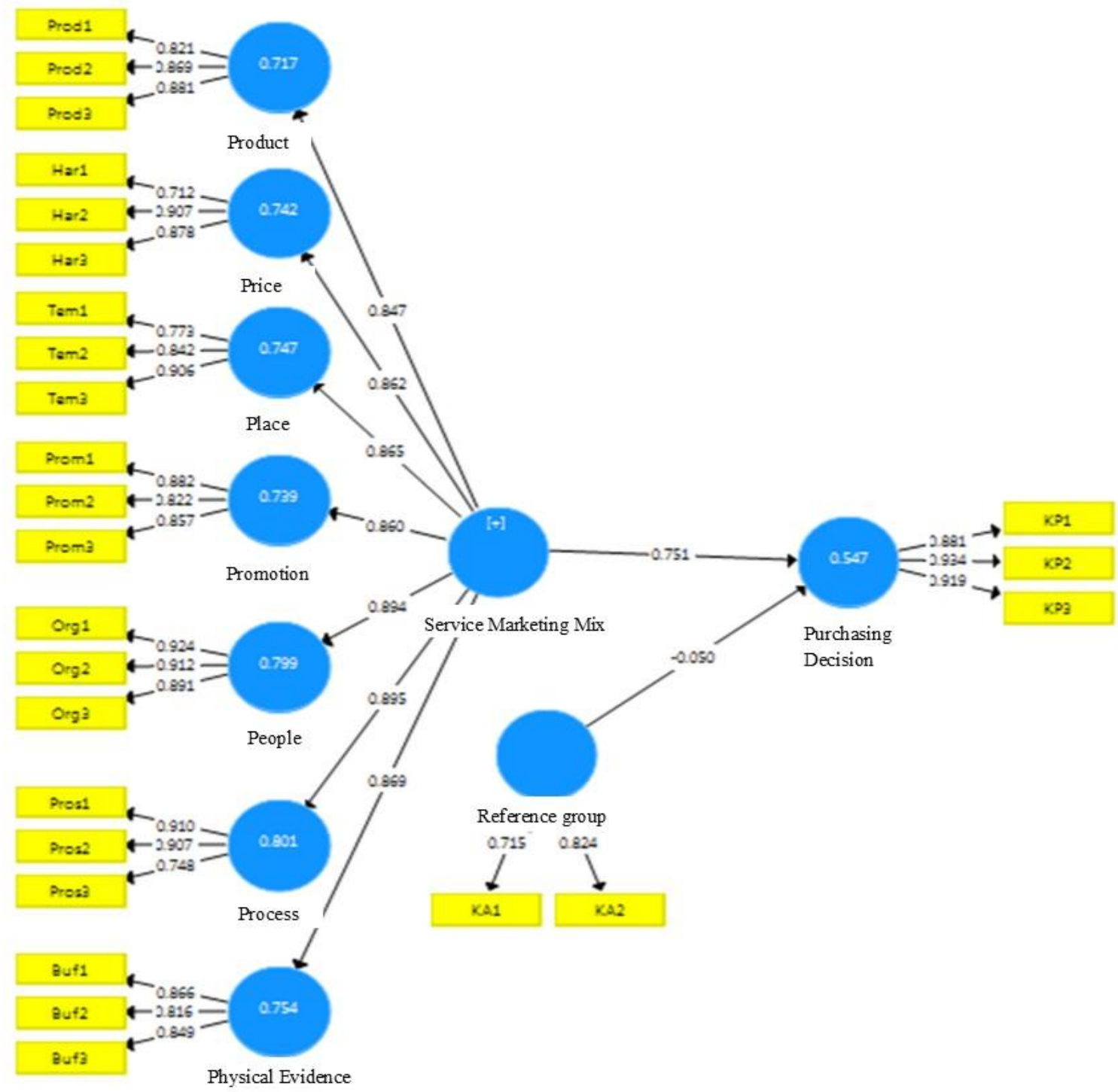

Figure 3. The path diagram of the overall model

Convergent Validity of Constructs. The basic principle of the convergent validity test is the manifest variables of a construct supposed to be highly correlated (Latan and Ghozali, 
2015). This test aims to test the indicators on each variable so that it can be ascertained that these indicators can describe the variables used in the study. These indicators are expected to be easily understood by respondents so that the results can be valid. Convergent validity test parameters can be known based on the results of the loading factor and average variance extracted (AVE) The results of the loading factors and AVE values are presented in Table 5.

Research indicators used in this study are valid because the loading factor value shows a value of more than 0.6 and can be seen in Table 5. According to (Latan and Ghozali, 2015), the rule of thumb for the loading factor value said to be valid is greater than 0.6. Apart from assessing the validity of the indicators, the validity of the variables was also analyzed through the AVE approach. The resulting AVE value has been more than 0.5. This shows that more than $50 \%$ of the variability of the variables can be explained by the indicators used in this study. The rule of thumb for the AVE value is said to be valid if it is more than 0.5 . Thus, it can be concluded that the variable indicators used are valid.

Table 5. Loading factor and AVE values

\begin{tabular}{|c|c|c|c|c|c|}
\hline Variable & Dimension & Code & $\begin{array}{l}\text { Loading } \\
\text { factor }\end{array}$ & Status & AVE \\
\hline \multirow{21}{*}{$\begin{array}{l}\text { Services } \\
\text { marketing } \\
\operatorname{mix}(\mathrm{MMJ})\end{array}$} & \multirow{3}{*}{ Product (Prod) } & Prod1 & 0.821 & Valid & \multirow{3}{*}{0.734} \\
\hline & & Prod2 & 0.869 & Valid & \\
\hline & & Prod3 & 0.881 & Valid & \\
\hline & \multirow{3}{*}{ Price (Har) } & Har1 & 0.712 & Valid & \multirow{3}{*}{0.700} \\
\hline & & Har2 & 0.907 & Valid & \\
\hline & & Har3 & 0.878 & Valid & \\
\hline & \multirow{3}{*}{ Place (Tem) } & Tem1 & 0.773 & Valid & \multirow{3}{*}{$0.70 s$} \\
\hline & & Tem2 & 0.842 & Valid & \\
\hline & & Tem3 & 0.906 & Valid & \\
\hline & \multirow{3}{*}{$\begin{array}{l}\text { Promotion } \\
\text { (Prom) }\end{array}$} & Prom1 & 0.882 & Valid & \multirow{3}{*}{0.729} \\
\hline & & Prom2 & 0.822 & Valid & \\
\hline & & Prom3 & 0.857 & Valid & \\
\hline & \multirow{3}{*}{ People (Org) } & Org1 & 0.924 & Valid & \multirow{3}{*}{0.827} \\
\hline & & Org2 & 0.912 & Valid & \\
\hline & & Org3 & 0.891 & Valid & \\
\hline & \multirow{3}{*}{ Process (Pros) } & Pros1 & 0.910 & Valid & \multirow{3}{*}{0.737} \\
\hline & & Pros 2 & 0.907 & Valid & \\
\hline & & Pros3 & 0.748 & Valid & \\
\hline & \multirow{3}{*}{$\begin{array}{l}\text { Physical } \\
\text { Evidence (Buf) }\end{array}$} & Buf1 & 0.866 & Valid & \multirow{3}{*}{0.712} \\
\hline & & Buf2 & 0.816 & Valid & \\
\hline & & Buf3 & 0.849 & Valid & \\
\hline \multirow{2}{*}{$\begin{array}{l}\text { Reference Group } \\
\text { (KA) }\end{array}$} & & KA1 & 0.715 & Valid & \multirow[t]{2}{*}{0.596} \\
\hline & & KA2 & 0.824 & Valid & \\
\hline \multirow{3}{*}{$\begin{array}{c}\text { Purchasing } \\
\text { Decision (KP) }\end{array}$} & & KP1 & 0.881 & Valid & \multirow{3}{*}{0.831} \\
\hline & & KP2 & 0.934 & Valid & \\
\hline & & KP3 & 0.919 & Valid & \\
\hline
\end{tabular}


Construct Discriminant Validity. The basic principle of the discriminant validity test is that different construct manifest variables should not be highly correlated (Latan and Ghozali, 2015). The aim is to test each indicator used on a variable that should have a high correlation on that variable, not on other different variables. The discriminant validity test parameters can be seen from the cross-loading value. Based on the measurement results, the cross-loading value according to the rule of thumb so it can be said to be valid. The crossloading value has been greater than 0.6 and does not have a value greater than the indicator value for other variables (Latan and Ghozali, 2015). In Table 6, we can see the results of the measurement of discriminant validity.

Table 6. Cross loading value

\begin{tabular}{l|lllllllll}
\hline & \multicolumn{1}{l}{ Buf } & Har & KA & KP & Org & Prod & Prom & Pros & Tem \\
\hline Buf1 & 0.866 & 0.686 & 0.173 & 0.648 & 0.685 & 0.592 & 0.608 & 0.773 & 0.569 \\
Buf2 & 0.816 & 0.484 & 0.192 & 0.480 & 0.446 & 0.502 & 0.737 & 0.475 & 0.581 \\
Buf3 & 0.849 & 0.543 & 0.254 & 0.465 & 0.638 & 0.594 & 0.686 & 0.619 & 0.628 \\
Har1 & 0.378 & 0.812 & 0.135 & 0.388 & 0.427 & 0.420 & 0.454 & 0.501 & 0.388 \\
Har2 & 0.680 & 0.907 & 0.226 & 0.728 & 0.735 & 0.674 & 0.623 & 0.782 & 0.685 \\
Har3 & 0.609 & 0.878 & 0.151 & 0.521 & 0.657 & 0.564 & 0.572 & 0.688 & 0.618 \\
KA1 & 0.131 & 0.231 & 0.715 & 0.096 & 0.215 & 0.075 & 0.121 & 0.275 & 0.204 \\
KA2 & 0.236 & 0.106 & 0.824 & 0.119 & 0.100 & 0.142 & 0.237 & 0.129 & 0.204 \\
KP1 & 0.519 & 0.569 & 0.147 & 0.881 & 0.542 & 0.554 & 0.502 & 0.579 & 0.506 \\
KP2 & 0.562 & 0.644 & 0.097 & 0.934 & 0.618 & 0.562 & 0.533 & 0.696 & 0.596 \\
KP3 & 0.645 & 0.619 & 0.142 & 0.919 & 0.630 & 0.603 & 0.556 & 0.661 & 0.555 \\
Org1 & 0.658 & 0.694 & 0.194 & 0.598 & 0.924 & 0.681 & 0.621 & 0.768 & 0.626 \\
Org2 & 0.624 & 0.661 & 0.144 & 0.609 & 0.912 & 0.670 & 0.607 & 0.777 & 0.642 \\
Org3 & 0.646 & 0.671 & 0.194 & 0.584 & 0.891 & 0.634 & 0.629 & 0.757 & 0.635 \\
Prod1 & 0.551 & 0.613 & 0.186 & 0.597 & 0.641 & 0.821 & 0.602 & 0.607 & 0.618 \\
Prod2 & 0.550 & 0.595 & 0.091 & 0.535 & 0.659 & 0.869 & 0.597 & 0.586 & 0.609 \\
Prod3 & 0.619 & 0.521 & 0.095 & 0.483 & 0.568 & 0.881 & 0.604 & 0.555 & 0.600 \\
Prom1 & 0.760 & 0.664 & 0.194 & 0.609 & 0.657 & 0.621 & 0.882 & 0.653 & 0.751 \\
Prom2 & 0.566 & 0.372 & 0.199 & 0.339 & 0.448 & 0.504 & 0.822 & 0.358 & 0.557 \\
Prom3 & 0.689 & 0.618 & 0.221 & 0.505 & 0.609 & 0.654 & 0.857 & 0.592 & 0.654 \\
Pros1 & 0.657 & 0.707 & 0.216 & 0.641 & 0.820 & 0.607 & 0.605 & 0.910 & 0.712 \\
Pros2 & 0.691 & 0.709 & 0.231 & 0.683 & 0.794 & 0.648 & 0.633 & 0.907 & 0.677 \\
Pros3 & 0.570 & 0.566 & 0.200 & 0.485 & 0.520 & 0.485 & 0.387 & 0.848 & 0.398 \\
Tem1 & 0.549 & 0.565 & 0.266 & 0.480 & 0.541 & 0.504 & 0.564 & 0.558 & 0.873 \\
Tem2 & 0.506 & 0.471 & 0.186 & 0.389 & 0.473 & 0.532 & 0.637 & 0.493 & 0.882 \\
Tem3 & 0.695 & 0.688 & 0.217 & 0.634 & 0.717 & 0.729 & 0.742 & 0.716 & 0.906 \\
\hline
\end{tabular}

Reliability of the construct. To prove the accuracy, consistency, and accuracy of instruments in measuring variables, variable reliability tests can be carried out through composite reliability values (Latan and Ghozali 2015). 
Table 7. Composite Reliability Value

\begin{tabular}{cc}
\hline $\begin{array}{c}\text { Variable } \\
\text { dimensions }\end{array}$ & Composite Reliability \\
\hline Prod & 0.892 \\
Har & 0.874 \\
Tem & 0.879 \\
Prom & 0.890 \\
Org & 0.935 \\
Pros & 0.893 \\
Buf & 0.881 \\
KA & 0.746 \\
KP & 0.936 \\
\hline
\end{tabular}

In Table 7, it can be seen that each variable has a composite reliability value greater than 0.7 , thus the variables used in the study are reliable because these values have fulfilled the specified rule of thumb.

Evaluation of the Results of the Structural Model (Inner Model). To predict the strength of the structural model, inner model evaluation is carried out. The determinant coefficient $\left(\mathrm{R}^{2}\right.$ test) and the path coefficient or t-statistics are the parameters used to evaluate the inner model. To measure the level of variation of changes in the independent variable (exogenous latent) on the dependent variable (endogenous latent) using the $\mathrm{R}^{2}$ value. The purchase decision in this study has an $\mathrm{R}^{2}$ value of 0.547 , meaning that the purchase decision can be explained by the service marketing mix and the reference group of $54.7 \%$, and the remaining $45.3 \%$ is influenced by other variables not included in this research model.

furthermore, the overall goodness of fit (GoF) evaluation can be done using a criterion called the GoF index (Latan and Ghozali, 2015). Based on these calculations, the GoF index value of this research model is 0.429 . The desired rule of thumb value is greater than 0.35 , which means that the model has strong predictive power (Latan and Ghozali 2015). Therefore, the predictive power of this study can be said to have been strong because it reached the specified criteria.

Hypothesis test. In the structural equation model, hypothesis testing is an advanced evaluation that can be done by testing the path coefficient. In hypothesis testing, the path coefficient is a coefficient that shows the level of significance. The hypothesis used in this study is a hypothesis with a t-statistic value greater than 1.96 at a $90 \%$ confidence level which is called a one-tailed hypothesis. In Table 12, you can see the results of hypothesis testing.

Table 12. Hypothesis test

\begin{tabular}{lllll}
\hline & $\begin{array}{c}\text { Path } \\
\text { coefficient }\end{array}$ & T-Statistics & P Values & Status \\
\hline $\begin{array}{l}\text { Reference Group->Purchase } \\
\text { decision }\end{array}$ & -0.050 & 0.869 & 0.385 & $\begin{array}{l}\text { Not } \\
\text { Significant } \\
\begin{array}{l}\text { Service Marketing mix- } \\
\text { >Purchasing decisions }\end{array}\end{array}$ \\
\hline
\end{tabular}


Based on Table 8 shows that the service marketing mix variable has a significant effect on the purchasing decision of wedding vendors it can be seen that the service marketing mix variable has a significant effect on the purchasing decisions of wedding vendors. The p-value owned less than 0.05 and the t-statistic is greater than 1.96. Thus, Hypothesis 1, namely the service marketing mix has a significant effect on purchasing decisions of wedding vendors, is accepted. Meanwhile, for the reference group variable, the t-statistics is less than 1.96 and the P-value is more than 0.05 . Thus, the reference group variable does not have a significant effect on the purchasing decisions of wedding vendors, which means that Hypothesis 2 is rejected.

The Effect of the Service Marketing Mix on Purchasing Decisions. The service marketing mix has a significant positive effect on purchasing decisions. The service marketing mix consists of seven dimensions, namely product (Prod), Price (Price), Place (Tem), Promotion (Prom), Person (Org), Process (Pros), and physical evidence (Buf). The seven dimensions of this service marketing mix are a consideration for consumers in buying products from the wedding vendors they use. By increasing the existing indicators in the service marketing mix, it will increase consumer purchasing decisions for wedding vendors.

Based on the loading factor value which can be seen in Figure 3, the variable dimension that most contributes to describing the service marketing mix variable is the process variable dimension (Pros) with a loading factor value of 0.895 and the person variable dimension (Org) with a loading factor value of 0.894 . Whereas in the purchasing decision variable (KP), the highest loading factor value is on the KP2 indicator (Satisfaction at the wedding vendor) with a loading factor value of 0.934 . Thus it can be concluded that by increasing the dimensions of the process variable (Pros) and Person (Org) in the service marketing mix variable, it will increase the purchasing decision (KP) which is best described by the KP2 indicator (Satisfaction at wedding vendors). In the process variable dimension (Pros), the Pros 1 indicator (easy ordering method) needs to be considered because the Pros 1 indicator has the highest loading factor value with a value of 0.910 . Whereas in the Person (Org) variable dimension, the Org1 indicator (friendly employees) is the indicator with the highest loading factor value, which is 0.924 .

The results of this study are by the research of (Purnama and Murwatiningsih, 2014) with the object of research visiting the Ranggawarsita Museum, Putra et al. (2015) with the object of research on delivery services, (Wulan et al., 2016) with the object of research into cinnamon restaurants, (Sukotjo and Radix, 2010) with the object of beauty clinic research, Kavanillah (2018) with the object of hotel research, (Ramadhanti, 2017) with the research object of Giant Supermarket which states that the marketing mix of services has a significant effect on purchasing decisions.

The Effect of Reference Groups on Purchasing Decisions. Based on hypothesis testing, the reference group does not have a significant effect on the purchasing decisions of wedding vendors. The reference group consists of two indicators, namely family recommendation (KA1) and recommendation from friends (KA2). Current consumer decisions based on research are not influenced by the reference group consisting of family and friends. This is due to the variety of respondents' answers. Some reference groups can have a positive effect, some others can have a negative effect on consumer purchasing 
decisions. So that there is no dominant relationship in this study which causes the relationship to be insignificant.

The purchasing decisions regarding wedding vendors are mostly made by the bride and groom. Reference groups can provide information to the bride but this information can be positive or negative. Information can be positive because the information provided by the reference group matches the needs of the bride. On the other hand, information can be negative because the information provided by the reference group does not match the needs of the bride.

Reference groups can influence consumer preferences or purchase intentions, but not necessarily influence purchasing decisions. Purchase preferences and intentions do not always result in actual purchase choices which can be caused by unexpected situational factors (Kotler and Armstrong, 2008). The results of this study are also supported by research by (Zahrah et al., 2016) which states that the reference group has no significant effect on purchasing decisions at the Kimbab Rina Malang restaurant, but has a significant effect on purchase intentions. In the research of (Ramadhan, 2017) also states that the reference group has no significant effect on the decision to purchase the Puri Hasanah Cluster 3 house. Besides, the research of (Sianturi et al., 2012) with the blackberry research object, and (Putra, 2014) with the iPhone research object also stated that the reference group did not have a significant effect on purchasing decisions.

Wedding Vendor Strategies in Influencing Consumer Purchase Decision. Marketing strategies that can be developed by wedding vendor business activists can be analyzed using the Importance Performance Analysis (IPA) method. This method is an analysis used to determine consumer responses to the indicator variables plotted in the diagram so that the priority level is known. Based on the results of the IPA analysis, priorities for the development of a service marketing mix that can be applied by wedding vendors will be obtained.

Table 13. The Level of Importance and Performance Indicators of the Service Marketing Mix Variable

\begin{tabular}{lccc}
\hline \multicolumn{1}{c}{ Dimensions } & Indicators & Importance & Performance \\
\hline \multirow{3}{*}{ Product(Prod) } & Prod1 & 0.821 & 3.639 \\
& Prod2 & 0.869 & 4.038 \\
& Prod3 & 0.881 & 4.053 \\
Price(Har) & Har1 & 0.712 & 3.861 \\
& Har2 & 0.907 & 4.014 \\
& Har3 & 0.878 & 4.226 \\
Place(Tem) & Tem1 & 0.773 & 3.707 \\
& Tem2 & 0.842 & 3.639 \\
& Tem3 & 0.906 & 3.851 \\
Promotions(Prom) & Prom1 & 0.882 & 3.476 \\
& Prom2 & 0.822 & 3.51 \\
People(Org) & Prom3 & 0.857 & 3.788 \\
\hline
\end{tabular}




\begin{tabular}{lccc}
\hline & Org2 & 0.912 & 4.005 \\
& Org3 & 0.891 & 4.048 \\
Process (Pros) & Pros1 & 0.910 & 4.019 \\
& Pros2 & 0.907 & 3.957 \\
& Pros3 & 0.748 & 3.764 \\
Physical & Buf1 & 0.866 & 4.01 \\
Evidence(Buf) & Buf2 & 0.816 & 3.558 \\
& Buf3 & 0.849 & 3.558 \\
\hline
\end{tabular}

Table 13 shows the value level of importance and performance of the indicator variables of each construct. The performance value is represented by the average value of the respondent's perception assessment performance, while the importance value is represented by the loading factor value of each indicator variable. The higher the performance value means that the indicator variable is the better, conversely, the lower the performance value indicates that the indicator variable is not very good. The importance value describes how strongly the indicator variable influences the construct, the greater the value, the greater the influence of the indicator variable in influencing the construct.

Then the values of Table 9 are plotted to produce a science diagram (Figure 4) to see the priority level of each indicator variable. Figure 4 is the result of the IPA diagram of the indicator variable which is directly connected to behavioral interest. The line $Y$ is obtained and drawn from the average value of all performance indicator variables of all constructs, which is 3,821 and the line $\mathrm{Z}$ is drawn from the average value of all the importance of all indicator variables, which is 0.853 .

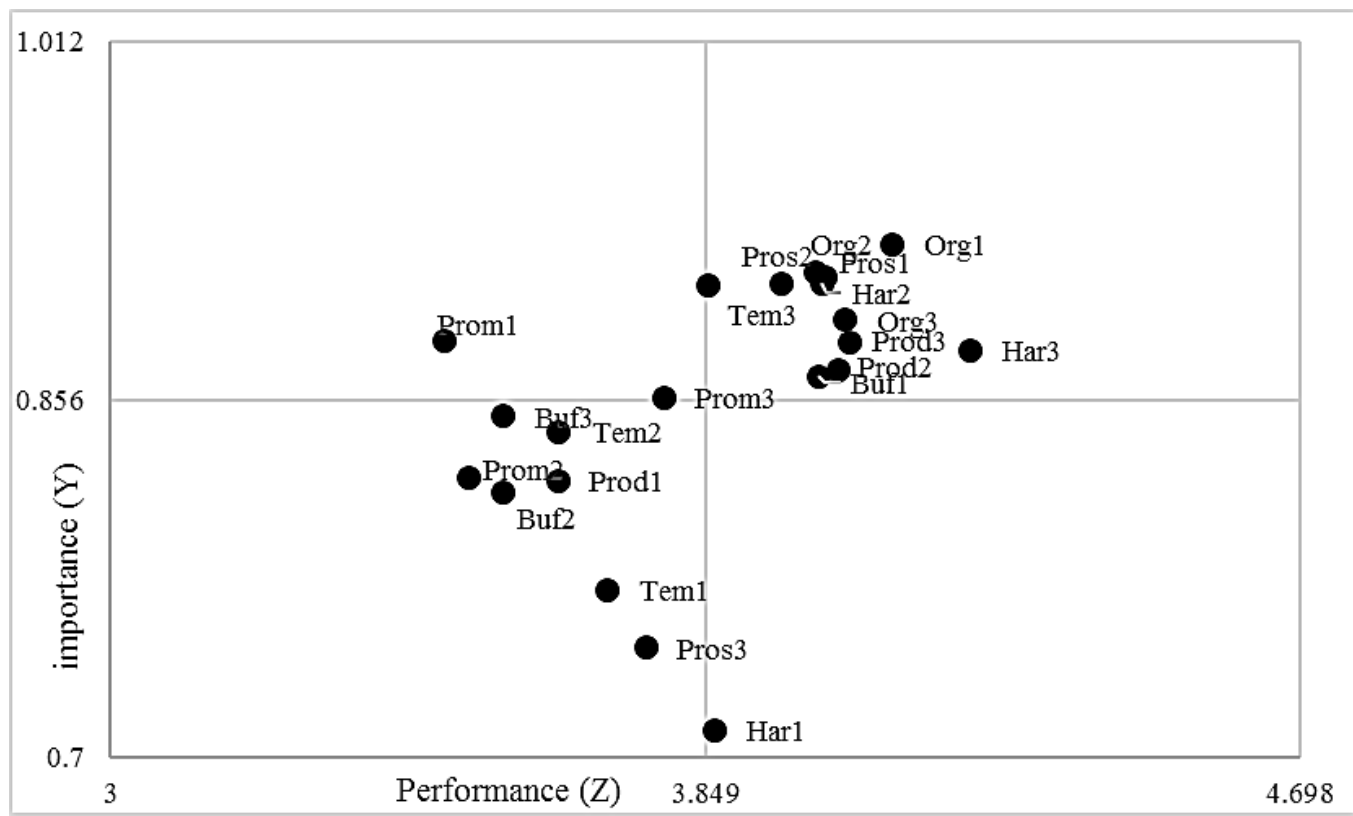

Figure 4. IPA Diagram 
In Figure 4, two indicator variables are in quadrant I, namely attractive advertisements (Prom1) and attractive promos (Prom3). The variable indicators in quadrant I are the main priority for improvement because they have a high level of importance in influencing the construction but still have low performance.

In quadrant II there are 11 variable indicators including complete product packages (Prod2), various product choices (Prod3), prices according to quality (Har2), ease of payment periods (Har3), guaranteeing product availability (Tem3), friendly employees (Org1), responsive employees (Org2), good product (Org3), easy ordering (Pros1), fast service process (Pros2), and an attractive portfolio (Buf1). The indicators in this quadrant have a high level of importance and already have good performance so they need to be maintained.

In quadrant III there are 7 indicator variables, including product quality (Prod1), being able to serve consumers outside the region (Tem1), strategic office locations (Tem2), participating in exhibitions (Prom2), making less involved (Pros3), display of websites or media socially attractive (Buf2) and attractive uniforms (Buf3). The variable indicators in this quadrant have a low priority for improvement because they have a low level of importance and low performance. The increase in the indicator variable that enters this quadrant can be reconsidered because its effect on consumer purchasing decisions is still below average.

In quadrant IV, there is one indicator, namely a lower price (Har1). The indicators in this quadrant are included in the excessive category because they have good performance even though their importance is low. The indicators in this quadrant can be somewhat neglected.

Managerial Implications. Based on the previous discussion, several things must be considered by wedding vendor businesses. The results of the analysis of consumer consumption behavior of wedding vendors produce an overview of wedding vendor consumers who can be the segment and target market of wedding vendors. For these consumers, the service marketing mix has a significant effect on the purchasing decisions of wedding vendors. Meanwhile, the reference group has no significant effect on the decision to purchase wedding vendors.

Table 14. Marketing strategy formulation based on STP

\begin{tabular}{ll}
\hline Segmentation and & Demographics: Female, domiciled in West Java, age 20-25 years, \\
Target Market & undergraduate education level, work as a housewife, spending 2.5 million-4 \\
million / month. & \\
& Consumption behavior: women as the main decision-maker, the source of \\
& funds comes from the two families of the bride and groom, with 3-6 months \\
& of preparation time, a budget of 50 million-100 million with $100-500$ guests, \\
& one wedding vendor which includes bridal make-up, decoration, catering, \\
& invitations, photography, and souvenirs.
\end{tabular}

Positioning

Complete product package, various product choices, price according to quality, easy payment period, guarantee the product availability, friendly employees, responsive employees, employees who master the product, easy ordering method, fast service process, and an attractive portfolio. 
Referring to the service marketing mix, based on the results of IPA analysis based on performance level data and the level of importance of indicators, several strategic priorities can be applied. First, priority indicators that can be improved to improve purchasing decisions are by increasing attractive advertisements and attractive sales promos. Advertising and sales promos are important in improving consumer purchasing decisions but their performance is still low according to consumer perceptions. The advertisements and sales promos used by wedding vendors are not yet optimal, so they need to be improved again. Second, the 11 indicators in Kudran II can be used as content to create attractive advertisements and sales promos or can be used as reference materials in developing wedding vendor positioning insight of consumers. Third, in addition to the 11 indicators, the consumer's consumption behavior of wedding vendors can also be used as a reference for building wedding vendor positioning in the eyes of consumers. In table 14, you can see the formulation of strategies based on the STP approach.

\section{CONCLUSION}

Consumers' perceptions of the service marketing mix and purchasing decisions are in a good category. Meanwhile, consumers' perceptions of the reference group are still in a fair category. Based on the research results, the service mix marketing has a significant positive effect on the purchasing decisions of wedding vendors. Meanwhile, the reference group has no significant effect on the decision to purchase wedding vendors. Marketing strategies that can be developed by wedding vendor business activists can be done by prioritizing the development of important factors in the service marketing mix whose performance is still under average, including attractive advertisements (Prom1) and attractive promotions (Prom3). To create attractive advertisements and attractive sales promos, 11 indicators have been recommended to be maintained. Managerial implications are formulated with an STP framework in which the segmentation and target market is by the results of the descriptive analysis of demographics and consumer consumption behavior of wedding vendors. For positioning, 11 indicators can be used in quadrant II, because these indicators have a high level of importance and high performance. As for differentiation, wedding vendors need to increase attractive advertisements and attractive sales promos, because these indicators are important but their performance is still below average and there are still many vendors who have not optimized attractive advertisements and attractive sales promos.

Suggestion. The object of this research is wedding vendors in general, therefore the strategy presented is a strategy that can be used by wedding business activists in general. This research can be further developed with a more specific object of research on one particular wedding vendor so that the strategies obtained will be more targeted according to the uniqueness and challenges of each wedding vendor.

\section{REFERENCES}

Bridestory. (2017). Laporan Tren Pernikahan 2017 Indonesia. [Diakses 18 Januari 2019]. Diunduh dari: https://www.bridestory.com. 
Chayana P.R., (2014). Pengaruh bauran pemasaran jasa "House of Balloon" terhadap niat beli ulang konsumen. Jurnal Manajemen. 13 (2): 131-150.

Edward L, and Eriksson C. (2014). Second-Hand Clothing Online: A Study of Swedish Consumer Purchasing Intentions [tesis]. Swedia (SE): University of Boras, The Swedish School of Textiles.

Fatrina D., Kamil I., and Hasan A. (2019). Pengaruh Live-Chat dan E-Wom terhadap Pengambilan Keputusan Transaksi Online pada Marketplace E-Commerce. Jurnal nasional teknologi dan sistem informasi. 5 (3):121-129.

Fernandes S, and Panda R. (2015). Social Reference Group Influence on Women Buying Behavior: A review. Journal of Commerce and Management Thought. 9: 273-291. Doi: 10.5958/0976-478X.2018.00019.8.

Fu G., Li Y., and Fei X. (2018). "The Evolution of Urban Wedding Consumption in China Since the 1970s". Journal of Contemporary Marketing Science. 1(1): 163-175 DOI: https://doi.org/10.1108/JCMARS-09-2018-0011.

Guan. L., Luoi Y., and Tangi L.R. (2015). “An Exploratoryystudyyof Decision Makerssfor Choosing WeddinggBanquet Venues: Push and Pull Motivations". International Journal of Tourism Cities. 1(2): 162-174 DOI: http;//dx.doi.org/10.1108/IJTC-082014-0011.

Harahap D.A., (2015). Analisis factor-faktor yang mempengaruhi keputusan pebelian konsumen di pajak usu (PAJUS) Medan. Jurnal Keuangan dan Bisnis. 7 (3): 227-242.

Huang H.C., Hou C.I., Hong Y.S., "Analysis of Importance of Professional Abilities Required by Personnel in Wedding Planner Services. International Journal of Organizational Innovation. 9(4): 157-170.

Kavanillah D. (2018). Pengaruh bauran pemasaran jasa terhadap keputusan menginap di Hotel Andita Syariah Surabaya. Iqtishoduna 7 (2): 146-164.

Kementerian.Agama.RI. 2016. Kementerian.agama RI dalam angka 2016. Jakarta (ID): Biro hubungan masyarakat data dan informasi. Diunduh dari: https://kemenag.go.id/home/artikel/43064

Kotler P, dan Amstrong G. (2008). Prinsip-Prinsip Pemasaran. Ed ke-12. Jakarta (ID): Erlangga.

Latan H, and Ghozali I. (2015). Partial Least Squares Konsep, Teknik dan Aplikasi. Semarang (ID): Badan Penerbit Universitas Diponegoro.

Marwa S., Sumarwan U., Nurmalina R. (2014). Bauran pemasaran memengaruhi keputusan konsumen dalam pembelian asuransi jiwa individu. Jurnal Ilmu keluarga dan Konsumen. 7 (3): 183-192.

Novita N.N., Sulistiyowati L., dan Musfar T.F. 2014. Pengaruh keluarga dan kelompok referensi terhadap keputusan konsumen membeli kosmetika khusus pria (studi kasus merek Vaseline men di Pekanbaru). JOM Fekon. 1 (2): 1-11.

Purnama M.S.A.C, and Murwatiningsih. (2014). Pengaruh Marketing mix terhadap Process Keputusan Berkunjung ke Museum Ranggawarsita Semarang. Management Analysis Joural. 1(3): 1-10.

Putra F. A. (2014). Pengaruh Gaya Hidup dan Kelompok Referensi terhadap Keputusan Pembelian. Jurnal Ilmiah Mahasiswa FEB. 3 (1): 1-14

Putra A.B, Yulianto E, and Sunarti. (2015). Pengaruh Bauran Pemasaran Jasa terhadap Keputusan Pembelian (Survei pada Pelanggan yang Menggunakan Jasa Pengiriman di Kantor Pos Besar Kota Malang). Jurnal Administrasi Bisnis (JAB). 1(1):1-8. 
Ramadhan. A. (2017). Pengaruh.Marketing mix, Motivasi.dan.Kelompok Acuan terhadap Keputusan.Pembelian.Rumah.Cluster Puri Hasanah 3 Depok.[tesis]. Bogor (ID): IPB.

Ramadhanti A. (2017). Pengaruh Bauran Pemasaran (7p) terhadap Keputusan. Pembelian. pada Giant Supermarket Mall Mesra.Indah di Samarinda. eJournal Administrasi Bisnis, 2017, 5 (2): 269-282.

Razak M.I., Ibrahim R, Abdullah N., Osman I., dan Alias Z. (2013). Purchasing Intention Toward Real Estate Development in Setia Alam, Shah Alam: Evidence from Malaysia. International Journal of Bussiness, Humanities, and Technology. 3(6): 6774.

Ris D.T.S. (2014). Pengaruh.Keluarga. dan Kelompok Acuan. Terhadap Keputusan Konsumen Membeli. Kosmetika Khusus Pria Merek. Garnier.Men (Studi Kasus Di Pekanbaru). JOM Fekon. 1(2): 1-11.

Sangkakoon P., Ngarmyarn A., and Panichpathom S. (2014). The Influence of Group Reference in Home Purchase Intention in Thailand. [tesis]. Thailand (TH): Thammasat University.

Schiffman L.G. and Wisenblit J.L. (2015). Consumer Behavior. Eleventh Edition. England: Pearson Education Limited.

Sianturi E., Erida., and Nifita A.T. (2012). Pengaruh Kelompok Referensi dan Gaya Hidup Terhadap Keputusan Menggunakan Blackberry. Jurnal Ekonomi Universitas Jambi. 1 (2): 127-136.

Sukotjo. H and Radix. S. A. (2010). Analisa Marketing mix 7P (Produk Price, Promotion, Place, Partisipant, Process, dan Physical Evidence) terhadap Keputusan.Pembelian Produk Klinik Kecantikan Teta diSurabaya. Jurnal Mitra.Ekonomi dan Manajemen Bisnis. 1(2): 216-2288.

Sumarwan U. (2014). PerilakuuKonsumen: Teori dan Penerapannya dalammPemasaran. Bogor (ID): GhaliaaIndonesia.

Tempo.co. 2017. Bisnis Pernikahan di Indonesia Capai US\$7 Miliar per Tahun. [Internet]. [Diakses pada 10 Januari 2019]. Dari: https://gaya.tempo.co/read/839343/bisnispernikahan-di-indonesia-capai-us7-miliar-per-tahun

Tjahjono A., Semuel H., and Brahmana R.K.M.R. (2013). Analisa marketing mix lingkungan social, psikologi terhadap keputusan online pakaian wanita. Jurnal Manajemen Pemasaran Petra. 1(2): 1-9

Tuwo H.J, and Pandowo M. (2015). The influence of social factors on customer purchase intention in using wedding organizer in Manado. Jurnal EMBA. 3 (3): 29-38

Wardhani W. (2015). Pengaruh persepsi dan kelompok acuan konsumen terhadap keputusan pembelian hunian green product. Jurnal Manajemen dan Organisasi. 6 (1): 45-63.

Widjaja. (2015). Pengambil Keputusan Konsumen Semarang dalam Memilih Vendor Pesta Pernikahan. Jurnal E-Komunikasi Universitas Kristen Petra. 3(2): 1-9.

Wulan WS., Mawardi MK., and Pangestuti E. (2016). Pengaruh Bauran. Pemasaran Jasa terhadap Keputusan. Pembelian Serta Dampaknya Terhadap Kepuasan. Pelanggan (Studi Pada Restoran. Kayu Manis Tuban). Jurnal Administrasi Bisnis (JAB) 38 (2): 176-183.

Yahya. (2011). Pengaruh Variabel Demografis Konsumen terhadap Keputusan Pembelian Produk (Studi. Pada Deterjen Merk. Soklin di Kecamatan Glagah Kabupaten Lamongan). JAMBSP 8 (1): 23 - 40. 
Yuniarti.Y. (2015). Pengaruh.Kelompok. Acuan dan. Keluarga terhadap. Keputusan. Pembelian Batik Jambi di Kota Jambi. Jurnal Penelitian Universitas Jambi Seri Humaniora. 17 (2): 9-18

Zeithaml V.A., Bitner MJ., and Gremler DD. (2018). Services Marketing: Integrating Customer Focus. Across The Firm. 7th Edition. New.York (US): McGraw-Hill Education.

Zahra N.H., Suharyono., dan Yulianto E. (2016). Pengaruh Kelompok Acuan terhadap Sikap dan Niat Pembelian, Serta Dampaknya pada Keputusan Pembelian. (Survei pada Konsumen. di Rumah Makan. Kimbap Rina, Malang). Jurnal.Administrasi Bisnis. (JAB) 37 (2): 192-199. 